\title{
Effect Adding PVA Polymer on Structural and Optical Properties of $\mathrm{TiO}_{2}$ Thin Films
}

\author{
Arwa Fadil Saleh*, Ahmed Mousa Jaffar, Najim A. Samoom ${ }^{* *}$ and Marwa Wailed Mahmmod** \\ *Department of Physics, College of Science, Al- Mustansiriyah University, Baghdad-Iraq. \\ ** Iraqi Ministry of Sciences and Technology. \\ E-mail: ahah1986_12_14@yahoo.com.
}

\begin{abstract}
Thin films of titanium dioxide $\mathrm{TiO}_{2}$ pure and $\mathrm{TiO}_{2}$ :PVA polymer were prepared using chemical spray pyrolysis technique on glass substrate preheated at $\left(350^{\circ} \mathrm{C}\right)$ for $\mathrm{TiO}_{2}$ pure, and at $\left(160{ }^{\circ} \mathrm{C}\right)$ for $\mathrm{TiO}_{2}$ :PVA. with spray rate $3 \mathrm{sec} . / 1 \mathrm{~min}$, and thickness $(250 \mathrm{~nm})$. The investigation of (XRD) indicates that structural of $\mathrm{TiO}_{2}$ pure and $\mathrm{TiO}_{2}$ : PVA thin films they are polycrystalline and XRD investigation is anatase titanium dioxide, intensity of $\langle 101\rangle$ is more than the intensity of $\langle\cdots \varepsilon\rangle$, $<200>$ and $<105>$ for $\mathrm{TiO}_{2}$ and $\mathrm{TiO}_{2}$ :PVA thin films. The optical properties measurement explain the effect of adding PVA on Transmittance, absorptance, refractive index, absorption coefficient and electronic transitions of prepared thin films. and their results observed that filling of PVA caused increase in optical properties generally.
\end{abstract}

Keywords: titanium dioxide $\mathrm{TiO}_{2}$, chemical spray pyrolysis, PVA, optical and structural properties, thin films.

\section{Introduction}

Recently conjugated polymers (cps) and inorganic compounds have been intensively investigated for the applications devices as light emitting diodes, photodiodes, sensor smart microelectronic and photovoltaic (cells) $[1,2,3] . \mathrm{TiO}_{2}$ have the outstanding proportion of high refractive index (N2.5), excellent transmittance in visible as well as high electrical and chemical stability. It has been studied extensively for using in optoelectronic device [4,5] $\mathrm{TiO}_{2}$ was used as electron accepting material because of its non-toxic and abundance availability to indentify physical and structural properties of semiconductor material, the scope of thin films has enabled this opportunity to study semiconductors through the preparation of films [6], because of easily breaking the thin film which is does not exceed only microns thick it is deposited on certain substrate, such as glass, silicon ,and alumina $^{[7]} \cdot \mathrm{TiO}_{2}$ is found naturally as white material, in three forms of crystalline, Rutile (tetragonal), Anatase (tetragonal), and Brokite (orthorhombic) ${ }^{[8]}, \mathrm{TiO}_{2}$ films can be prepared by different techniques, such as thermal evaporation in vacuum deposition (TEVD), chemical vapor deposition (CVD), pulse laser deposition (PLD) chemical spray pyrolysis deposition (CSPD) and other method ${ }^{[9,10,11]}$.
Polyvinyl Alcohol (PVA) is a white and granular, it is soluble in hot water but insoluble in cold water and common organic solvents for many applications ${ }^{[12]}$, this polymer chose in this research because of its relative ability for preheating (comparing with other polymers) to deposited on glass. Polyvinyl Alcohol is prepared in water solutions on evaporation of water, transparent films are formed which have high tensile strength and tear resistance ${ }^{[6]}$, PVA polymer has a melting point of $180^{\circ} \mathrm{C}^{[13]}$ and it has a molecular weights $(26,300,72,000$ and $30,000) \mathrm{g} / \mathrm{mol}^{[14]}$. The aim of this research is study adding PVA polymer on some structural and optical properties of $\mathrm{TiO}_{2}$ thin films which prepared by chemical spray pyrolysis technique.

\section{Experimental Work}

$\mathrm{TiO}_{2}$ were prepared by chemical spray pyrolysis technique, which spraying an aqueous solution of titanium chloride $\mathrm{TiCl}_{3}$, which prepared with $(0.1 \mathrm{ml} / \mathrm{mol})$ by dissolving in distilled water $(50 \mathrm{ml})$ of $\left(\mathrm{H}_{2} \mathrm{O}\right)$, then the resulting solution was sprayed on clean preheated glass substrate at $\left(350^{\circ} \mathrm{C}\right)$. $\mathrm{TiO}_{2}$ thin films were formed according to equation $^{[15]}$ : 
$2 \mathrm{TiCl}_{3}+\mathrm{H}_{2} \mathrm{O} \stackrel{\bullet}{\rightarrow} \mathrm{Ti}(\mathrm{OH})_{2} \mathrm{Cl}_{2}+\mathrm{TiCl}_{4}$

$\mathrm{Ti}(\mathrm{OH})_{2} \mathrm{Cl}_{2} \stackrel{\oplus}{\rightarrow} \downarrow \mathrm{TiO}_{2}+\uparrow 2 \mathrm{HCl}$

The resulting films were transparent, white yellowish coulor, stable free from pen holes and have good adhesive property .measured by Two method weight and micro balance. The selected thickness were (250nm).

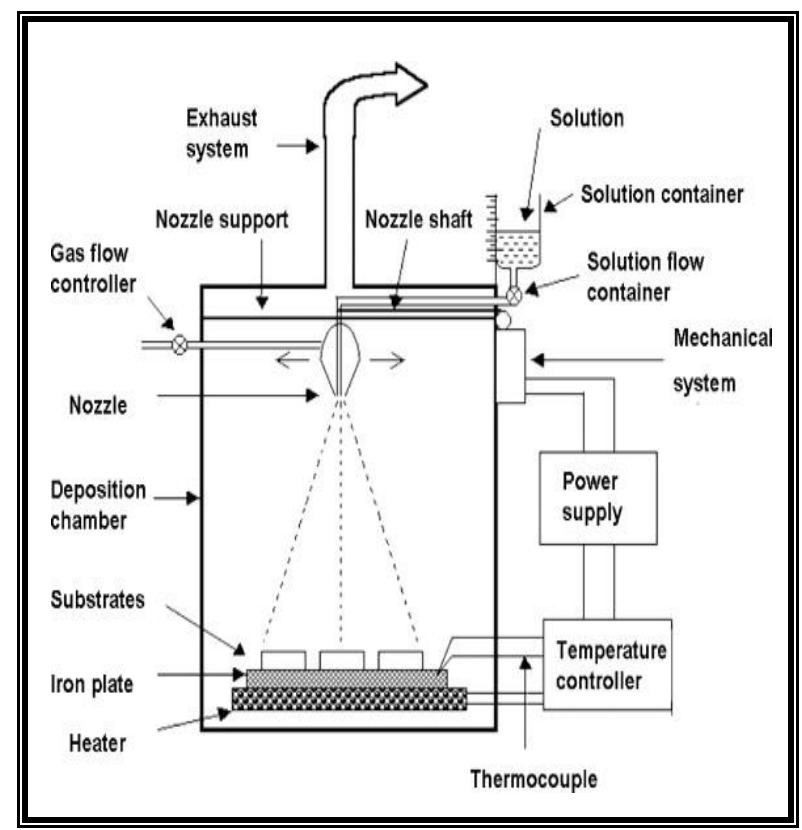

Fig.(1) Equipments of chemical spray pyrolysis system.

To prepare titanium dioxide doped polymer (poly vinyl alcohol) is added $(0.065 \mathrm{~g})$ of PVA to the distilled water and they solves exposure solution to heat with constant stirring and after confirmation of soluble polymer is added to the solution titanium chlorides $\mathrm{TiCl}_{3}$ record advance and then sprayed on the slides glass and degree temperature $160{ }^{\circ} \mathrm{C}$ producing $\mathrm{TiO}_{2}: \mathrm{PVA}$ with same thickness $(250 \mathrm{~nm})$.

\section{Results and Discussions}

A. XRD analysis: The crystalline structure for $\mathrm{TiO}_{2}$ and $\mathrm{TiO}_{2}$ : PVA can be recognized by studying the phase of (XRD) for that material, when a beam of (XRD) from mono wavelength incident on film surface, will exhibit peaks on limit angels for each material because of reflecting of Bragg on parallel crystalline surface. XRD instrument is from type (Shimadzu 6000) made in Japan, with the following specifications are Target is $\mathrm{Cuk}_{\alpha \square}$,
Wavelength is $1.5406 \mathrm{~A}$, Current is 30 (mA.) and Voltage is $(40 \mathrm{KV}$.). The XRD find that structural of $\mathrm{TiO}_{2}$ thin film it is polycrystalline and XRD investigation is anatase titanium dioxide, intensity of $<101>$ is more than the intensity of $<\cdots \varepsilon>,<200>$ and $<105>$ which agrees with (ASTM) card, for $\mathrm{TiO}_{2}$ and $\mathrm{TiO}_{2}$ :PVA, as shown in Fig.(2).

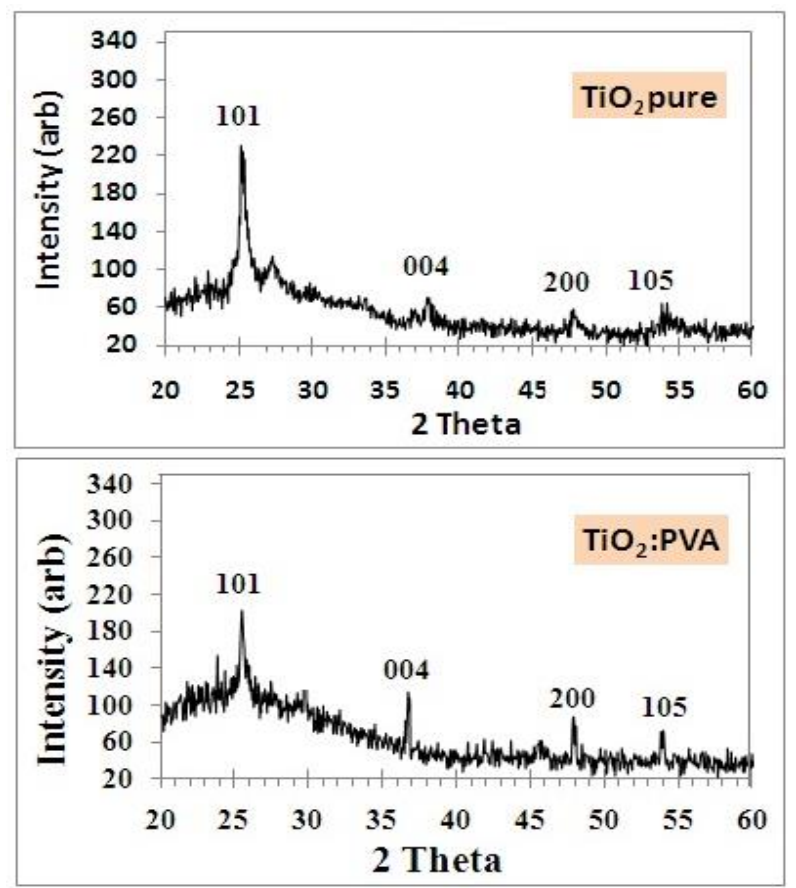

Fig.(2) XRD pattern of $\mathrm{TiO}_{2}$ pure and $\mathrm{TiO}_{2}: \mathrm{PVA}$ thin films.

Lattice constancies (a) and (c) can calculate from the following equation:

$\frac{1}{d^{2}}=\frac{h^{2}+k^{2}}{a^{2}}+\frac{l^{2}}{c^{2}}$

XRD pattern is observed characteristics diffraction peaks corresponding to the $<101>$, $<004>,<200>$ and $<105>$ The values which measured by XRD instrument of diffraction

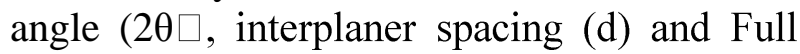
Width at Half Maximum (FWHM) are shown in Table (1) which it emerged adding PVA polymer enhanced the structural properties of $\mathrm{TiO}_{2}$ thin films that means the degree of crystalline increases because the molecules of $\mathrm{TiO}_{2}$ come close together. 
Table (1)

Some structural properties for $\mathrm{TiO}_{2}$ pure and $\mathrm{TiO}_{2}: \mathrm{PVA}$ thin films.

\begin{tabular}{|c|c|c|c|c|c|c|c|}
\hline substrate & hkl & $d A^{o}$ & $2 \theta$ & $\begin{array}{c}F W H M \\
(\beta)\end{array}$ & $\begin{array}{c}D_{\text {ave. }} \\
A^{o}\end{array}$ & $a A^{o}$ & $c A^{o}$ \\
\hline $\mathrm{TiO}_{2}$ pure & $\begin{array}{l}101 \\
004 \\
200\end{array}$ & $\mid \begin{array}{l}3.52125 \\
2.37769 \\
1.89835\end{array}$ & $\begin{array}{l}25.2721 \\
37.8063 \\
47.8792\end{array}$ & $\begin{array}{l}0.9233 \\
0.5917 \\
0.7000\end{array}$ & 1.5723 & 3.7906 & 9.5107 \\
\hline $\mathrm{TiO}_{2}: \mathrm{PVA}$ & $\begin{array}{l}101 \\
004 \\
200 \\
105\end{array}$ & $\mid \begin{array}{l}3.49702 \\
2.47889 \\
1.87732 \\
1.69990\end{array}$ & $\begin{array}{l}25.4502 \\
36.2081 \\
48.4497 \\
53.8501\end{array}$ & $\begin{array}{l}0.1636 \\
0.1962 \\
0.1083 \\
0.1150\end{array}$ & 8.5829 & 3.7172 & 9.9155 \\
\hline
\end{tabular}

\section{B. Optical properties}

(1) Transmittance and Absoptance

The transmittance and absorptance of prepared films were measured using (UV-1650PC Shimadzu software 1700 1650, UV-Visible recording Spectrophotometer), (Phillips), Japanese company in the wavelength range (300-850 $\mathrm{nm}$ ), it is found the transmittance decreasing with add polymer that behavior is vice versa with absorpance behavior as in Fig.(3), which means the PVA polymer enhancement the $\mathrm{TiO}_{2}$ thin films absorptance, this attributed that when adding PVA to $\mathrm{TiO}_{2}$ solutions these molecules fills the vacancies between polymer chains.

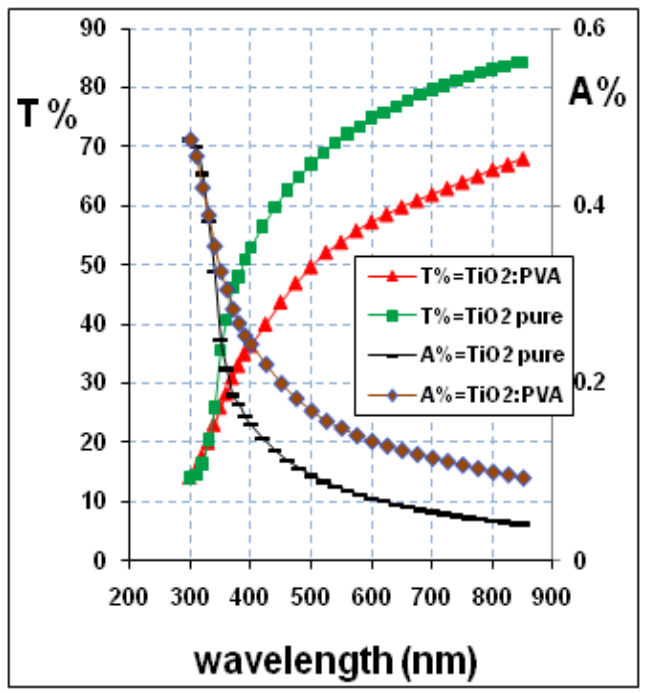

Fig. (3) Transmittance and absorptance of $\mathrm{TiO}_{2}$ pure, $\mathrm{TiO}_{2}: \mathrm{PVA}$ thin films.

\section{(2) Absorption coefficient ( $\alpha$ )}

The absorption coefficient $(\alpha)$ of thin films prepared was calculated in the fundamental absorption region from the relation ${ }^{[7]}$ :

$\alpha=2.303 \frac{A}{t}$
Where: A : absorptance of the thin film.

$\mathrm{t}$ : thickness of thin film, which is $250 \mathrm{~nm}$.

Fig.(4) shows the relation of absorption coefficient as a function of incident photon energy for $\mathrm{TiO}_{2}$ thin films. The figure shows the high variation. Also we can evidently see that $\mathrm{TiO}_{2}$ thin films have high value of absorption coefficient $\left(\alpha>10^{4} \mathrm{~cm}^{-1}\right)$ which leads to increasing the probability of occurrence direct transitions. From the same figure we can notice an increasing in absorption coefficient when we add PVA. This is due to the formation of localized levels near the edge of connection, that means this decreasing could be attributed to the changes in the particle size distribution function of formed thin films.

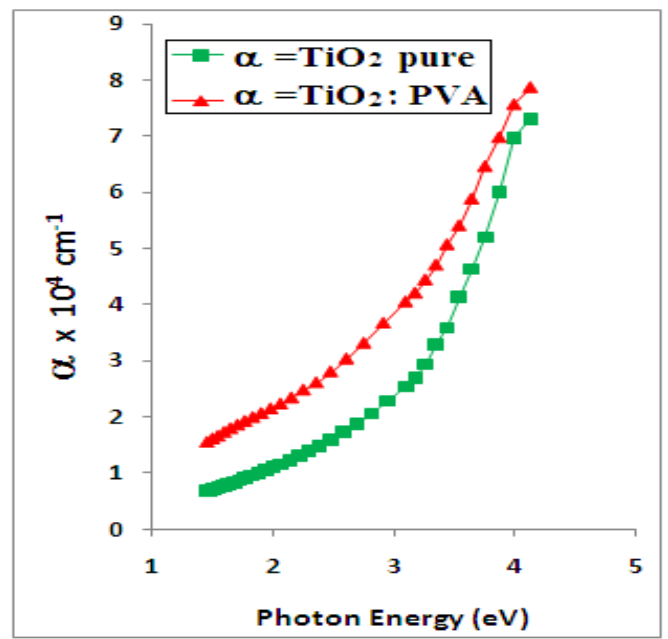

Fig.(4) Absorption coefficient of $\mathrm{TiO}_{2}$ pure, $\mathrm{TiO}_{2}: \mathrm{PVA}$ thin films.

\section{(3) Refractive index (n)}

The refractive index (n) of the prepared thin films was calculated according to the following equation ${ }^{[10]}$.

$$
n=\frac{1+\sqrt{R}}{1-\sqrt{R}}
$$

Where R: reflectance of thin film.

Fig.(5) shows the variation of refractive index (n) with photon energy of the prepared thin films. The increase may be attributed to higher packing density and the changes in the particle size distribution function of $\mathrm{TiO}_{2}$ structural, this the enhancement of growth crystalline this attributed to the molecules of $\mathrm{TiO}_{2}$ come close together when add PVA polymer $^{[3,6]}$. 


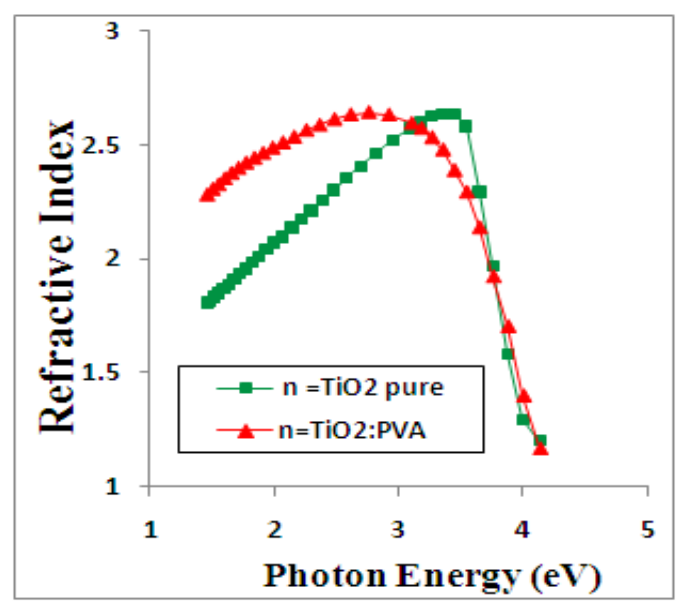

Fig. (5) Refractive Index of $\mathrm{TiO}_{2}$ pure, $\mathrm{TiO}_{2}: \mathrm{PVA}$ thin films.

\section{(4) Energy gap $\left(E_{g}\right)$}

All electronic transitions for the prepared thin films were studied, the direct allowed energy gap in the fundamental absorption region of $\mathrm{TiO}_{2}$ thin films was calculated from relation: ${ }^{[16]}$

$\alpha h v=B\left(h v-E_{g}\right)^{r}$

Where:

hv: photon energy.

$E_{g}$ : direct allowed energy photon.

B: constant depends on the type of transition.

r: exponential constant, its value depended on type of transition,

$\mathrm{r}=1 / 2$ for the allowed direct transition.

$r=3 / 2$ for the forbidden direct transition.

Fig.(6-a) shows the relation of $(\alpha h v)^{2}$ against photon energy, from straight line obtained at high photon energy the direct allowed energy gap could be determined which was equal $(3.195 \mathrm{eV})$ at thickness (250nm), and Fig.(6-b) shows direct forbidden energy gap equal $(3.052 \mathrm{eV})$. The increase may be attributed to the improvement of growth crystalline that leads to crystallinity of anatase phase $^{[17]}$.
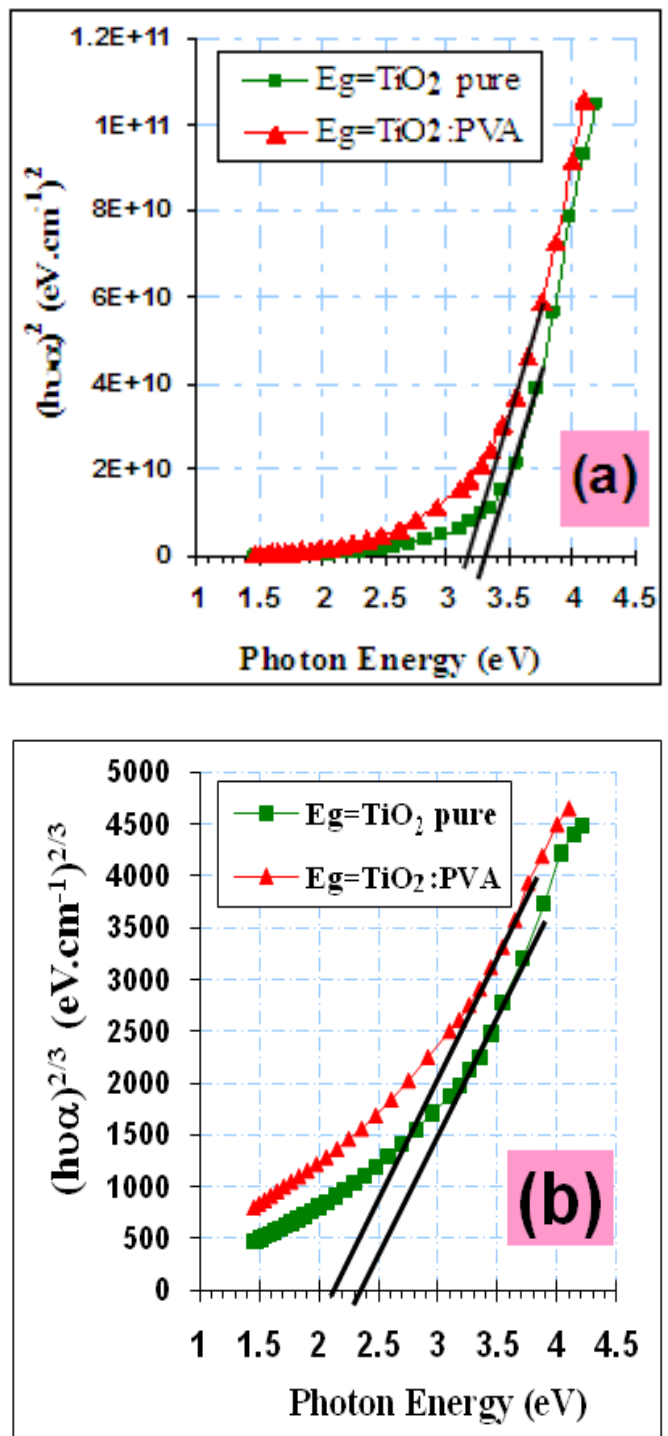

Fig. (6) electronic transitions of $\mathrm{TiO}_{2}$ pure, $\mathrm{TiO}_{2}: \mathrm{PVA}$ thin films. (a) allowed direct transition, (b) forbidden direct transition.

Table (2)

Optical constants of $\mathrm{TiO}_{2}$ pure, $\mathrm{TiO}_{2}: \mathrm{PVA}$ thin films.

\begin{tabular}{||l||c||c||}
\hline \multicolumn{1}{|c||}{$\begin{array}{c}\text { Optical } \\
\text { Constants }\end{array}$} & $\begin{array}{c}\mathrm{TiO}_{2} \\
\text { pure }\end{array}$ & TiO $_{2}:$ PVA \\
\hline \hline $\mathrm{T} \%$ & 84.29 & 67.95 \\
\hline \hline $\mathrm{A} \%$ & 9.02 & 16.7811 \\
\hline \hline & $\begin{array}{c}73100 \\
\mathrm{~cm}^{-1}\end{array}$ & $\begin{array}{c}78658.69 \\
\mathrm{~cm}^{-1}\end{array}$ \\
\hline $\mathrm{n}_{\mathrm{o}}$ & 2.57 & 2.64 \\
\hline \hline $\begin{array}{l}\text { Allowed Energy } \\
\text { Gap Eg }\end{array}$ & $3.352 \mathrm{eV}$ & $3.195 \mathrm{eV}$ \\
\hline $\begin{array}{l}\text { Forbidden } \\
\text { Energy Gap } \mathrm{E}_{\mathrm{g}}\end{array}$ & $2.383 \mathrm{eV}$ & $2.011 \mathrm{eV}$ \\
\hline
\end{tabular}




\section{Conclusions}

The following major conclusions be drawn from this work on the doped dependence on optical properties and the crystalline structure for $\mathrm{TiO}_{2}$ and $\mathrm{TiO}_{2}$ : PVA prepared thin films:

1. XRD pattern is observed characteristics diffraction peaks which measured by XRD

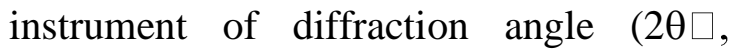
interplaner spacing (d) and Full Width at Half Maximum (FWHM), PVA enhances the general structural properties of $\mathrm{TiO}_{2}$ thin films that means PVA increased tie-up of bonds between $\mathrm{Ti}$ and $\mathrm{O}$ atoms which means the molecules of $\mathrm{TiO}_{2}$ come close together.

2. Prepared thin films have high values of absorption coefficient for the wavelength range $(300-850 \mathrm{~nm})$, It is increased when add PVA polymer.

3. Absorption and refractive index of $\mathrm{TiO}_{2}$ thin films increase as film doped with PVA.

4. The direct allowed energy gap of $\mathrm{TiO}_{2}$ and $\mathrm{TiO}_{2}$ : PVA thin films was (3.195$3.052 \mathrm{eV})$ respectively, and forbidden energy gap was $(2.109-2.383 \mathrm{eV})$ for $\mathrm{TiO}_{2}$ and $\mathrm{TiO}_{2}$ : PVA thin films respectively. This means the PVA decreased the energy gap of $\mathrm{TiO}_{2}$.

From enhancements for structural results, absorption and electronic transitions for optical properties of $\mathrm{TiO}_{2}$ thin films prepared, can be using it as benefactor of solar cells after adding PVA polymer.

\section{References}

[1] Jae-Yeol Lee, W.Y.Lee, Duck-Kyun Choi, Jei Oh. "Structure and properties of Co doped $\mathrm{TiO}_{2}$ thin films on Si (100) by pulsed laser deposition method", "J.Ceramic Processing Res.", Vol.(7), No.(1), pp.(5861), 2006.

[2] Doushita K. and Awahara T., "Evaluation of Photocatalytic Activity by Dye Decomposition”, "Journal of Sol-Gel Science and Technology”, 22, 91-98, 2001.

[3] Ram A., Fundamentals of polymer engineering, Plenum Press, New York, p. 51, 1997.

[4] Donald. A.N., "Semiconductor Physics and Devices", Irwin, USA, 1992.
[5] Zhang C., Yuan X., Wu L., Han Y., Sheng J., "Study on morophology of electrospun (poly vinyl alcohol) mats", Eur. Polym. J., 41, pp. 423-432, 2005.

[6] RADOIČIĆ M., ŠAPONJIĆ Z. V., MARINOVIĆ M. T. ,CINCOVIĆ, S. P. AHRENKIEL, BIBIĆ N. M. and NEDELJKOVI J. M., "The influence of shaped $\mathrm{TiO}_{2}$ nanofillers on the thermal properties of poly (vinyl alcohol)", "Journal of Serbian Chemical Society", 76 (0), pp.(1-23), 2011

[7] Chopra K.L., "Thin films phenomena", Mc.Graw-Hill, NewYork, 1969.

[8] M.Landmann, E. Rauls and W, G, Schmidt, "The electronic structure and optical response of rutile, anatase and brookite $\mathrm{TiO}_{2}$," J.Phys.: Condens. Matter, 24, 195503, 2012.

[9] Chopra K.L., "Thin Film Devices Application", Plenum Press, New York, 1983.

[10] Eckortova L., "Physics of Thin Films", (plenum press), 1977.

[11] Hasan M.M., Hasseeb A.S.M.A., Saidur R., Masjuki H.H., "Effect of annealing treatment on optical properties of anatase $\mathrm{TiO}_{2}$ thin films", "International Journal of Chemical and Bimolecular Engineering", Vol.1, pp.93-97, 2008.

[12] Chide B. T., AL-Wattar A. H., Al-Tememee N. A. A., Twej W. A., Hameed M. A., Ubaid A. Q., Sallman Q. M. and Redha A. B., "Study the Effect of the High Voltage on The preparation of Polyvinyl Alcohol/ $\mathrm{TiO}_{2}$ Nano Fiber by Electrospinning", "Iraqi Journal of Physics”, Vol. 7, No.8, pp. 21- 24, 2009.

[13] Piorkowska E. and Galeski A. "Thermal conductivity of polymers", International Polymer Science and Technology, Vol.12, No.5. (1985).

[14] Koski A., Yim K., Shivkumar S.;"Effect of molecular weight on fibrous PVA produced by electrospinning"; Mat. Letter; 58; 493, 2004.

[15] Areej Adnan Hateef, Batool Daram Balawa, Arwaa Fadil Saleh and Marwa Wailed Mahmmod, "Effect of the thickness on electrical properties of $\mathrm{TiO}_{2}$ thin films, prepared by thermal chemical spray pyrolysis deposition", "International 
Research Journal of Engineering Science, Technology and Innovation (IRJESTI)" Vol.(1), N(6), pp.(175-179), 2012.

[16] Nilens A.G., "deep imparity in semiconductors", Wiley -Interscience publication, 1973.

[17] Ristolainen N., Heikkilä P., Harlin A., and Seppälä J., "Electro spun Nanofibers Prepared by two methods: in situ emulsion polymerized $\mathrm{PVA} /$ nanoTiO $_{2}$ and mixing of functional PVA with nanoTiO ${ }_{2}$ ", "AUTEX Research Journal”, Vol. (8), No. (2), 2008.

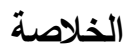

حُضرث أغشية ثناني أوكسيد التبتانيوم الرقيقة النقية و المشوبة بالبوليمر TiO2

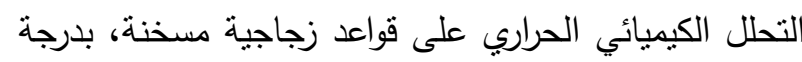
حرارة (350 ( 350) لتحضير أغشية ثناني أوكسيد التنتانيوم الرقيقة النقية الاغشية المشوبة بالبوليمر TiO

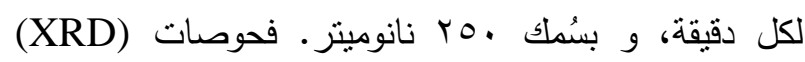
بينت ان التركيب أغثية $\mathrm{TiO}_{2}$ بأنها متعددة التبلور $\mathrm{TiO}_{2}: \mathrm{PVA}$

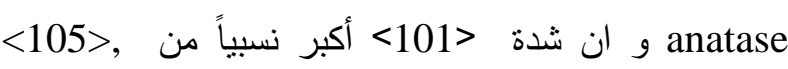

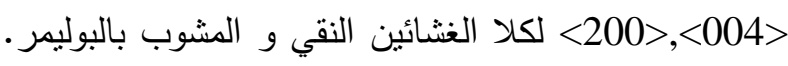

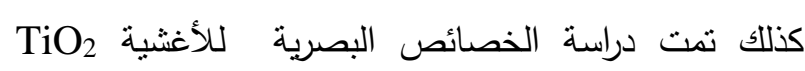

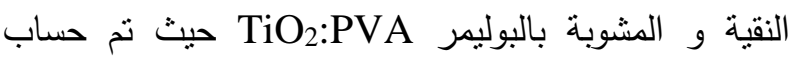
الثوابت البصرية قبل و بعد إضافة البوليم PVA كالنفاذية،

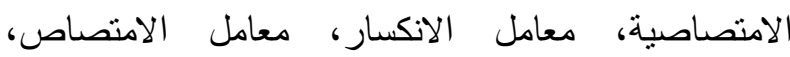

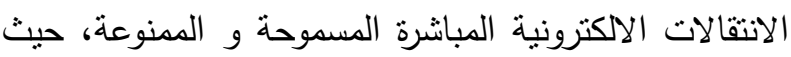

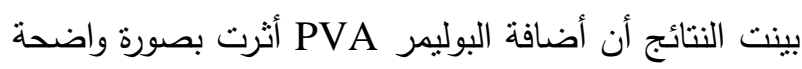

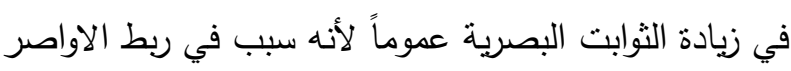

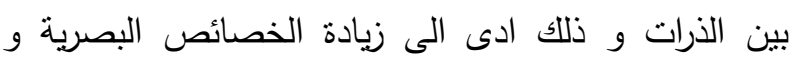
التركيبية أيضاً. 